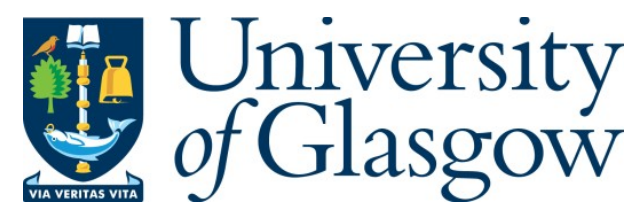

Yang, S., Isa, S., Ramayah, T., Wen, J. and Goh, E. (2021) Developing an extended model of self-congruity to predict Chinese tourists' revisit intentions to New Zealand: the moderating role of gender. Asia Pacific Journal of Marketing and Logistics (Early Online Publication)

(doi: 10.1108/APJML-05-2021-0346)

This author accepted manuscript is deposited under a Creative Commons Attribution Non-commercial 4.0 International (CC BY-NC) licence. This means that anyone may distribute, adapt, and build upon the work for non-commercial purposes, subject to full attribution. If you wish to use this manuscript for commercial purposes, please contact permissions@emerald.com.

There may be differences between this version and the published version. You are advised to consult the publisher's version if you wish to cite from it.

http://eprints.gla.ac.uk/253056/

Deposited on: 29 October 2021

Enlighten - Research publications by members of the University of Glasgow http://eprints.gla.ac.uk 


\section{Developing an Extended Model of Self-congruity to Predict Chinese Tourists' Revisit Intentions to New Zealand: The Moderating Role of Gender}

Shaohua Yang ${ }^{1}$ Salmi Mohd Isa ${ }^{2}$ T. Ramayah ${ }^{3}$ Jun Wen ${ }^{4}$ Edmund Goh ${ }^{5}$

${ }^{1,2}$,Graduate School of Business, Universiti Sains Malaysia, 11800 Penang, Malaysia Email: samuelyang0713@hotmail.com; salmi.mohd.isa@usm.my;

${ }^{3}$ School of Management, Universiti Sains Malaysia, 11800 Penang, Malaysia Email: ramayah@usm.my

${ }^{4,5}$ School of Business and Law, Edith Cowan University, 270 Joondalup Drive, Joondalup WA 6027, Australia

Email: e.goh@ecu.edu.au

Note: Jun Wen is corresponding author and can be contacted at: j.wen@ecu.edu.au 


\begin{abstract}
Purpose - This study developed an extended model of self-congruity by integrating destination image, destination personality, self-congruity, revisit intention and gender.

Design/methodology/approach - Surveys were conducted with 645 Chinese tourists visiting New Zealand. Partial least squares structural equation modelling (PLS-SEM) was performed to estimate linkages between destination image, destination personality, self-congruity, and revisit intention. To compare effects on revisit intention across male and female Chinese tourists, PLS-Henseler's multigroup analysis and PLS-permutation test were conducted to analyze gender as a moderator in the proposed framework.

Findings - Our results revealed positive direct effects among destination image, destination personality, self-congruity, and revisit intention. Our findings indicated a highly significant difference in the effects of destination personality on ideal self-congruity across male and female Chinese tourists. The association between destination image and self- congruity identified through this model represents a crucial contribution to the tourism literature. This study also enriches tourism research by comparing male and female Chinese tourists' intentions to revisit New Zealand, having identified crucial heterogeneity within female tourists.
\end{abstract}

Practical implications - The practical implications from our research can improve destination marketing organization (DMO) officials' awareness of one-time and repeat Chinese tourists' experiences, which strongly trigger subsequent visits.

Originality/value - This paper is the first to examine the direct correlations among destination image, destination personality, self-congruity, and revisit intention by considering whether gender might moderate these factors. Our study innovatively adopted PLS-SEM along with several advanced analytical approaches, such as multigroup analysis (MGA) of women and men, to examine our research model.

Keywords: Chinese tourist; New Zealand; PLS-multigroup analysis; theory of self-congruity; gender; destination image. 


\subsection{Introduction}

Self-congruity is indispensable to the evaluation of travel behaviour but presents challenges for destination marketing organizations (DMOs) given its key role in revisit intention (Sirgy \& Su, 2000; Usakli \& Baloglu, 2011; Chua et al., 2019; Tran et al., 2021). The theory of selfcongruity maintains that tourists are likely to choose destinations whose personality attributes align with individuals' self-concept (i.e., their own personality) (Pan et al., 2017). For instance, people tend to select locations that reflect their social status, personality traits, and lifestyle (Ekinci et al., 2013). In most cases, travellers take time to determine whether a destination's personality suits their self-concept; some like to experience tourism products and services personally before evaluating their purchases. Although a plethora of studies (Usakli \& Baloglu, 2011; Liu et al., 2012; Chen \& Phou, 2013; Xie \& Lee, 2013; Kumar, 2016; Chua et al., 2019; Gyulavári, \& Malota, 2019; Yang, Isa, \& Ramayah, 2020; Yang et al., 2020) have modelled the linkage among destination image, destination personality and self-congruity to predict revisit intention, an integrative model combining gender remains omitted from the tourism literature. Within tourism and hospitality research, gender has been identified as a critical determinant of such behaviour (Han et al., 2017; Jiang \& Chen, 2019; Yang et al., 2020; Rasoolimanesh et al., 2021) compared with other demographic variables. Furthermore, the effects of gender can vary based on other characteristics (Fishcher \& Arnold, 1994). However, no empirical examination has yet considered a model integrating destination image, destination personality, self-congruity, revisit intention, and gender-related factors among women and men. Differences in female and male tourists' perceptions of these constructs could uniquely influence their revisit intentions.

The objectives of this study are twofold. First, we sought to investigate the effects of destination image, destination personality, and self-congruity on revisit intention. Second, we examined the moderating role of gender within the proposed framework via multigroup analysis (MGA). Study results are expected to make three key contributions. First, theoretically, the integrative model could clarify possible correlations among these variables to enrich theory development. Second, from a managerial standpoint, the implications can improve DMO officials' awareness of one-time and repeat tourists' experiences, which might influence subsequent visits. Last, from a methodological perspective, we innovatively adopted partial least squares structural equation modelling (PLS-SEM) along with several advanced analytical approaches, such as multigroup analysis (MGA) of women and men, to examine our research model. 


\subsection{Literature Review}

\section{1 Destination image}

A destination's image consists of a series of impressions, ideas, expectations, and emotional reactions to that place (Assaker, 2014). This construct greatly affects individuals' decisions (Um \& Crompton, 1990; Allameh et al., 2015). In tourism, theories of destination image have proposed that a location's image includes the cognitive and affective images people associate with a destination's characteristics (Chen \& Uysal, 2002; Kim \& Richardson, 2003). A destination's conative image is more idealized and can inspire a person to engage in selfdevelopment (Dann, 1996). These multiple components have been addressed by many tourism scholars (Kaur et al., 2016; Stylos et al., 2016; Fu, Ye, \& Xiang, 2016). Studies have clearly described how destinations' cognitive, affective, and conative images explain individuals' travel behaviour (Hallmann et al., 2015). Although the cognitive and affective components of a destination have been found to predict its conative image (i.e., tourists' behavioural intentions) (Kani et al., 2017; Yang, Isa, \& Ramayah, 2021a), the interrelationships among these components are unclear (Stylos et al., 2016). Attitude theory posits that cognition, affect, and conation are linked by a sequential cause-and-effect relationship (Fishbein \& Ajzen, 1975).

Despite previous literature (Hallmann et al., 2015) showing that multiple components can clarify the effects of destination image on travel behaviour, these components can also be studied separately to capture their complexity (Li et al., 2010; Stylos et al., 2016). Destination image research varies in its foci; no consensus exists regarding destination attributes, and the measurement of destination image depends on scholars' objectives (Chaulagain et al., 2019). Cognitive destination image has been studied most frequently; for instance, psychological functional attributes ranging from cultural attractions, landscape/surroundings, nature, and entertainment and nightlife to shopping facilities (Gallarza, Saura, \& Garcia, 2002) are commonly adopted (e.g., Baloglu \& McCleary, 1999) to explain destination image. To disentangle the nuances of destination image, several tourism scholars have conceptualized the construct as unidimensional, such as by focusing on cognitive image (Jalilvand et al., 2012; Chen \& Phou, 2013; Isa, \& Ramli, 2014; Souiden et al., 2017; Zhang et al., 2018; Jeong, \& Kim, 2019).

Available empirical evidence explored the effect between destination image and destination personality (Hosany et al., 2006) However, destination personality must be differentiated from destination image (Kim et al., 2018), as these are distinct but related constructs (Hosany et al., 
2006). From a theoretical point of view, destination image refers to tourists' beliefs and knowledge about a destination (Bagozzi, 1978) and can help them discern a destination's personality (Xie \& Lee, 2013). However, the connection between destination image and destination personality remains largely ambiguous (Souiden et al., 2017). More importantly, destination image and destination personality are often examined separately; only a few studies have empirically investigated these topics simultaneously to unravel their interrelationship (Chen \& Phou, 2013; Souiden et al., 2017). More empirical testing is needed, hence the below hypothesis:

H1: Destination image has a positive influence on destination personality.

\subsection{Self-congruity}

The theoretical underpinnings of self-congruity originated from the theory of self-concept. The terms "self-image" and "self-congruence" are often used interchangeably (Matzler et al., 2016). The theory of self-congruity speaks to the cognitive consistency between consumers' selfconcept and a product/service or brand image (Sirgy et al., 1997; Sirgy \& Su, 2000). This theory is rooted in social psychology, suggesting that consumers' personalities can be partly identified based on the products, services, and brands they choose (Ross, 1971).

Although the theory of self-congruity implies that products, suppliers, and services possess a personal image just as people do (Sirgy, 1982), this theory has been described in various ways within the social sciences (Luna-Cortés et al., 2019). Sirgy (1982) suggested the prospect of multiple selves and outlined four facets of one's self-concept: the actual self, ideal self, social self, and ideal social self. In the marketing and consumer behaviour literature, researchers have viewed these facets as multidimensional constructs (Sirgy et al., 2000; Shamah et al., 2018). Actual self-congruity reflects how consumers view themselves, ideal self-congruity refers to how consumers wish to view themselves, social self-congruity indicates how consumers believe others view them, and ideal social self-congruity captures how consumers wish to be viewed by others. Among these aspects, most studies have only operationalized the actual and ideal dimensions (Usakli \& Baloglu, 2011; Abel, Buff, \& O’Neill, 2013; Yang et al., 2020; Yang, Isa, \& Ramayah, 2020; 2021b). In line with this research stream, the current paper considers self-congruity on the basis of the actual and ideal dimensions (e.g., Hosany \& Martin, 2012). As stated by Ekinci and Riley (2003) pointed out, it is plausible to address actual and ideal self-congruity together, as both belong to the personal dimension of self-concept. The 
social dimension of self-concept (i.e., the social self) is closely associated with actual ideal self-congruity (i.e., personal dimension) (Ekinci \& Riley, 2003).

Furthermore, destination personality and self-congruity represent two key cognitive variables in destination marketing. Destination personality encompasses the set of human personality traits tied to a destination (Ekinci \& Honsay, 2006), whereas self-congruity reflects the fit between tourists' self-concept and a destination's personality (Chua et al., 2019; Yang, Isa, \& Ramayah, 2021b). Although self-congruity includes four dimensions (i.e., the actual, ideal, social, and ideal social self), we focused on actual and ideal self-congruity because these dimensions have been thoroughly empirically investigated and are common in related research (Sirgy, 1982; Sirgy et al., 1997; Usakli \& Baloglu, 2011). Therefore, the cognitive stage of our model consisted of destination personality and self-congruity. Aaker (1999) discovered that consumers prefer brands whose personalities are similar to their own. In tourism contexts, a destination's brand personality has been found to differentiate regional travel. Better selfcongruity ratings also appear to be related to better destination personality ratings (Chua et al., 2019). We therefore hypothesize the following:

H2: Destination personality has a positive influence on actual self-congruity.

H3: Destination personality has a positive influence on ideal self-congruity.

In destination marketing, most relevant research has applied self-congruity to forecast behavioural intention, especially consumers' purchase intentions (Das, 2015; Das \& Khatwani, 2018). One's purchase intentions generally depend on their self-concept. Other scholars have identified a direct effect between self-congruity and customer loyalty in contexts such as the retail industry (Das, 2015) and fast food industry (Shamah et al., 2018). Regarding tourists' loyalty towards a destination, Liu et al. (2019) and Kim and Malek (2017) found self-congruity to strongly influence tourists' behavioural loyalty. This empirical evidence informs the following hypotheses:

H4: Actual self-congruity has a positive influence on revisit intention.

H5: Ideal self-congruity has a positive influence on revisit intention. 


\subsection{Conceptualizing gender}

An overarching theory has revealed that women's and men's decision-making processes and behaviour vary (Eagly \& Wood, 1991). Gender role theory posits that men are more courageous and self-dependent, whereas women are more likely to abide by social mores, express themselves emotionally, and show empathy for others (Zhang et al., 2017). Gender affects all aspects of decision making and behaviour (Riquelme \& Rios, 2010).

In studies of travel behaviour, gender has been identified as a prime determinant of destination choices and future purchases (Wang et al., 2016; Huang et al., 2019; Yang et al., 2020). Compared with research on other demographic factors (i.e., educational background, income level, marital status, or religion), gender is readily observable in investigations of how this construct shapes travellers' decisions (Han et al., 2017). However, gender-specific tourism research is limited because many studies assume that most tourists are men (Rasoolimanesh et al., 2021). Yet gender is important to consider in destination market segmentation. Studies have shown that gender informs traveller segmentation in domains such as sex tourism (Wen et al., 2020), girlfriend getaways (Chen \& Mak, 2020), solo female travellers (Karagöz et al., 2020), and Asian female travellers (Yang et al., 2018). Even so, few studies have considered gender differences in terms of entertainment, travel patterns, and travel and experience preferences (Pung et al., 2019). Gender, as a social and psychological concept, is thus likely to exert a moderating effect on certain social psychological mechanisms driving tourists' behaviour (Huang \& van der Veen, 2019).

\subsection{The moderating role of gender}

In this study, gender is taken as a categorical variable and is expected to moderate the effects of constructs in the proposed framework (i.e., destination image, destination personality, selfcongruity, and revisit intention). Studies have pinpointed discrepancies in perceived destination image based on gender. For instance, in the case of a Spanish destination, female tourists rated cultural/natural resources and leisure infrastructure significantly more highly than men did (Beerli \& Martin, 2004). Scholars have repeatedly emphasized the role of personality in depicting destinations (Kumar \& Nayak, 2018; Pan et al., 2017) versus alternative types of brand masculinity. The roles that masculine and feminine dimensions play in destination perceptions thus warrant further investigation (Pan et al., 2021). Šagovnović and Kovačić (2020) postulated that female and male tourists would perceive a destination's personality differently. According to gender schema theory, gender is a superficial feature that is highly 
indicative of personal attractiveness and is central to one's self-concept (Bem, 1981). Researchers have validated a self-congruity scale that includes actual gender congruity and ideal gender congruity (Pan et al., 2020; Pan et al., 2021). Women may be more likely than men to self-assess their physical appearance (Jones, 2011). Furthermore, gender-based explorations in hospitality have shown that women are more inclined than men to revisit a particular restaurant and that each gender's dining experience varies (Han \& Ryu, 2007). Gender is therefore anticipated to greatly affect destination image, destination personality, selfcongruity, and travel behaviour.

The tourism literature contains several studies on the moderating effect of gender on destination image and destination personality (Kim et al., 2018), destination personality and self-congruity (Moons et al., 2020), and self-congruity and revisit intention (Yang et al., 2020). Even so, gender has not been considered as a moderator among destination image, destination personality, self-congruity, and revisit intention within a single study. The relationships among these constructs are expected to vary by gender as postulated below:

H6: Gender moderates all relationships among variables in the research model.

H6a: The positive relationship between destination image and destination personality is stronger for female Chinese tourists than for male Chinese tourists.

H6b: The positive relationship between destination personality and actual self-congruity is stronger for female Chinese tourists than for male Chinese tourists.

H6c: The positive relationship between destination personality and ideal self-congruity is stronger for female Chinese tourists than for male Chinese tourists.

H6d: The positive relationship between actual self-congruity and revisit intention is stronger for female Chinese tourists than for male Chinese tourists.

H6e: The positive relationship between ideal self-congruity and revisit intention is stronger for female Chinese tourists than for male Chinese tourists. 


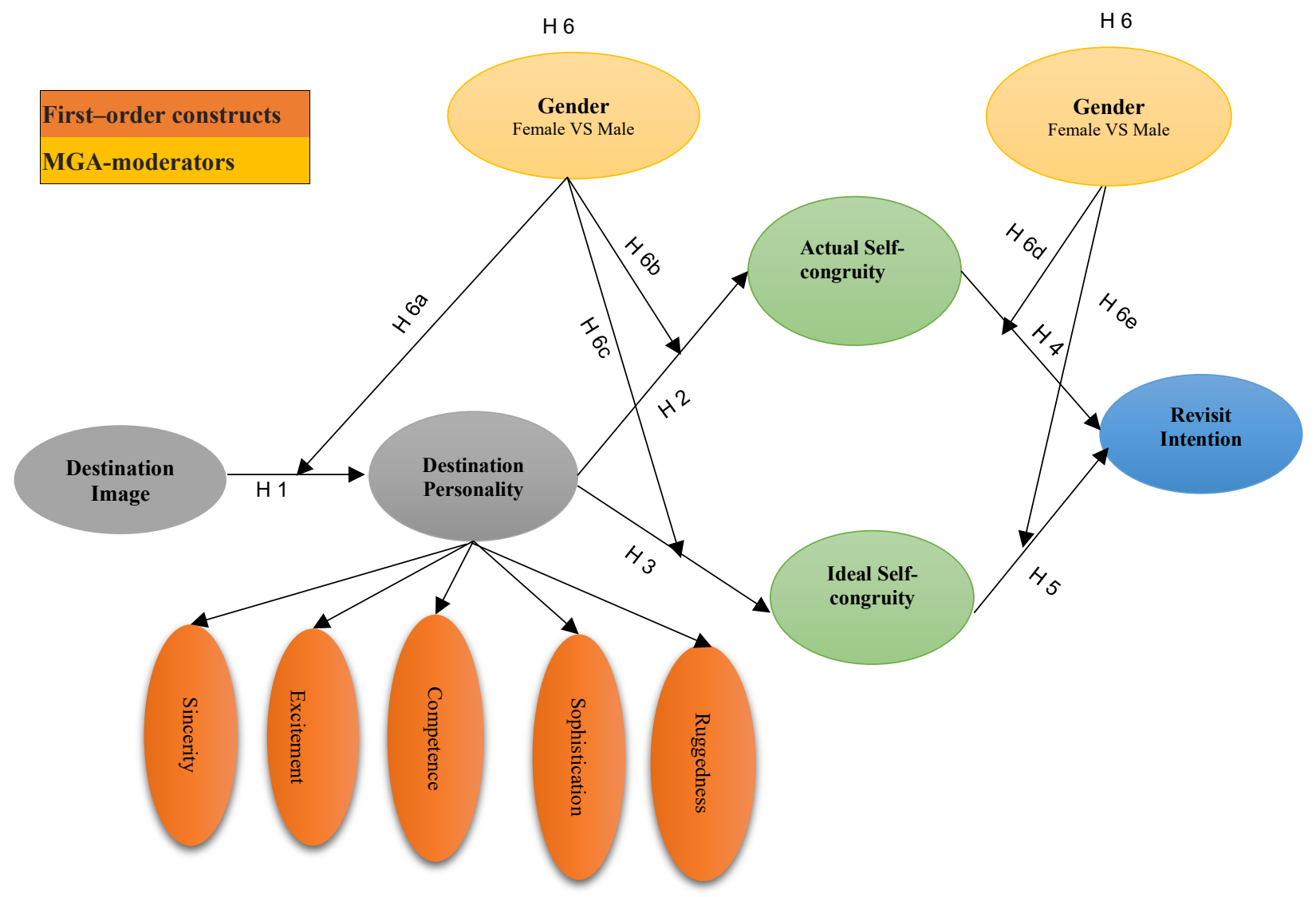

Figure 1. Theoretical Framework

\subsection{Methodology}

\subsection{Study site and context}

New Zealand (Maori: Aotearoa) is a small developed nation in the South Pacific Ocean and is home to roughly five million people. The country continues to welcome a growing number of international tourists to enjoy its sun, sand, wildlife, and adventure activities (World Journey, 2021). Tourism in New Zealand accounts for about $\$ 16.2$ billion of its gross domestic product (Tourism New Zealand, 2019). The island has been named the "land of long white clouds," a slogan incorporated into marketing campaign to promote the destination to Chinese tourists. This effort has drawn a large number of Chinese visitors to the country (Tourism New Zealand, 2017): more than 50,900 Chinese tourists have come to New Zealand, representing its largest tourist market by nationality (Statistic New Zealand, 2019). Regarding what the Chinese find 
appealing about New Zealand, Ryan and Mo (2002) cited the country's natural scenery and green, unpolluted environment. These attributes allow travellers to escape their busy lives, relax, and pursue adventure.

DMOs in New Zealand have successfully marketed to Chinese tourists. However, promoting these tourists' revisit intentions is equally as important to the country's sustainable tourism development. Attracting repeat tourists can also benefit DMOs' implementation of costeffective marketing strategies (Yang, Isa, \& Ramayah, 2020). Therefore, this study explored the antecedents of Chinese tourists' revisit intentions to offer insight for DMOs in New Zealand to attract repeat Chinese tourists.

\subsection{Measurement}

A quantitative design was employed to assess the research model. A two-part survey was developed to gather primary data. The first section included questions related to respondents' demographics (gender, age, marital status, education level, and household income). The second part covered the four variables of interest in this study: destination image, destination personality, self-congruity, and revisit intention. Five items on destination image were adapted from Jalilvand et al. (2012). Six items on self-congruity (including dimensions of the actual and ideal self) were taken from Usakli and Baloglu (2011) and Kumar (2016). Three items pertaining to revisit intention were adopted from Yang et al. (2020).

Destination personality included five dimensions with 15 items adapted from Chua et al. (2019) and Huaman-Ramirez et al. (2021). Although destination personality has been framed as a multidimensional construct (Huaman-Ramirez et al., 2021), Hair et al. (2014) indicated that constructs can be modelled as second-order factors to reduce the number of hypotheses in a structural model and make a PLS structural model more parsimonious. In accordance with Ringle, Sarstedt, and Straub's (2012) guidelines on second-order constructs, destination personality was conceptualized in this study as a reflective-reflective second-order construct (i.e., considering first- and second-order relationships to be reflective). Fifteen items representing five interrelated first-order constructs - sincerity, excitement, competence, sophistication, and ruggedness - corresponded to a higher-order factor of destination personality. 
Due to the nature of our sample (Chinese tourists whose first language was Chinese), a bilingual Chinese-English questionnaire was developed. The original questionnaire was translated into Chinese by members of our research team who were proficient in both languages. Back-translation was adopted to ensure accuracy (Brislin, 1970; Ye et al.,2020). The team members interviewed three tourism academics, and the phrasing of several questionnaire items was revised based on experts' feedback.

\subsection{Sample and data collection}

A cross-sectional survey was conducted with Chinese tourists from several New Zealand cities (i.e., Auckland, Hamilton, and Rotorua). Although focusing on one nation can limit results' generalizability, a cross-sectional survey is the most established research design that constrains plausible explanations for the dependent variable (Huaman-Ramirez et al., 2021). We employed non-probability (judgemental) sampling to identify potential respondents. Specifically, the main investigator flew to New Zealand to collect data between September and December 2019. The main investigator personally interacted with potential respondents before conducting the official survey (e.g., asking about possible respondents' nationality/residency status, visa type, and length of stay). These questions guaranteed a qualified sample. Eligible Chinese tourists were then invited to complete the questionnaire in person. The main researcher was available to explain survey items if respondents had questions while completing the survey. In total, 660 questionnaires were distributed, and 645 were retained for analysis. However, 15 surveys were discarded due to incomplete responses. A sample size between 200 and 500 is generally considered suitable for multivariate data analysis (Hair et al., 2009). Several tour leaders and the general manager of Deer Museum in Rotorua, New Zealand assisted with the survey distribution; as such, the effective response rate was quite high $(98.1 \%)$.

Table 1 summarizes respondents' demographic profile by gender, age, marital status, income, and education level. Slightly more than one-third (36.7\%) of Chinese tourists in our sample were men, and $63.3 \%$ were women. Respondents fell into five age groups: below age 25 (49.1\%), 25-35 (26.7\%), 36-45 (13.2\%), 46-55 (8.2\%), and age 55 and above (2.8\%). Young Chinese tourists thus appeared more eager to visit New Zealand. Most respondents were either single (65\%) or married (29.8\%), suggesting that single Chinese tourists were more interested in visiting New Zealand. Regarding monthly household income, about one-quarter $(24.8 \%)$ of respondents earned 10001-20000 RMB; 40\% earned more than 20000 RMB. Our sample 
appeared to be aware of New Zealand travel requirements: to obtain a visitor visa, Chinese tourists must present strong financial means and a clear budget/travel plan to an immigration officer. In terms of respondents' education level, most tourists in our sample held either a bachelor's degree (54.4\%) or a master's degree (16.7\%).

Table 1 Demographic Profile

\begin{tabular}{llll}
\hline Demographic factor & Categories & Frequencies & Percentages \\
\hline Gender & Male & 237 & 36.7 \\
Age & Female & 408 & 63.3 \\
& Below 25 years old & 317 & 49.1 \\
& 25-35 years old & 172 & 26.7 \\
36-45 years old & 85 & 13.2 \\
& 46-55 years old & 53 & 8.2 \\
Marital status & Older than 55 years old & 18 & 2.8 \\
& Married & 192 & 29.8 \\
& Single & 421 & 65.3 \\
& Divorced & 24 & 3.7 \\
& Widow & 7 & 1.1 \\
Monthly household income & Widower & 1 & 0.2 \\
& Less than 5000 RMB & 117 & 18.1 \\
& 5000-10000 RMB & 110 & 17.1 \\
& 10001-20000 RMB & 160 & 24.8 \\
Education level & More than 20000 RMB & 258 & 40 \\
& Postgraduate Level & 153 & 23.6 \\
& Undergraduate Level & 417 & 64.6 \\
& Secondary Level & 70 & 10.9 \\
& Other & 5 & 0.8 \\
\hline
\end{tabular}

\subsection{Data analysis}

Data analysis involved two phases: (1) testing the associations among variables using a conceptual model and (2) conducting MGA. We adopted PLS-SEM to analyze the hypothesized relationships and evaluate the research model (Ringle, Wende, \& Becker, 2015). PLS-SEM is a nonparametric test intended to minimize the proportion of unexplained variance; this method uses the weighted components of indicator variables to improve reliability (Ringle et al., 2015; Hair et al., 2017). Following guidelines from the PLS-SEM handbook and related literature, we employed a two-step approach to data analysis (Hair et al., 2017; Hair et al., 2019). We first evaluated our measurement model on the bases of inter-item reliability, convergent validity, and internal consistency. Then, we assessed the structural model to examine each hypothesis and assess its predictive power (Henseler et al., 2009). 
PLS-SEM was also adopted in the second phase because nonparametric SEM approaches are well-suited to MGA (Hair et al., 2014; Henseler et al., 2016). To evaluate our model via PLSSEM for female and male tourists, we evaluated the model (i.e., reliability and validity of reflective constructs). Then, two nonparametric approaches, Henseler's MGA and a permutation test, were conducted (Rasoolimanesh et al., 2017). Before proceeding to MGA, we evaluated measurement invariance using measurement invariance of composite (MICOM), a recent technique update to PLS-SEM.

\subsection{Measurement model assessment}

Table 2 shows that the CR value for each construct exceeded the benchmark of 0.7 , suggesting satisfactory internal consistency (Hair et al., 2017). Convergent validity was also supported: factor loadings were between 0.66 and 0.98, and all AVE values surpassed the recommended 0.50 threshold (Hair et al., 2017). As our model included second-order constructs, we adopted a two-stage method to evaluate our measurement model (Sarstedt et al., 2019). The five focal dimensions, as latent variables, were transformed into five indicators of destination personality (see Table 2). All items displayed factor loadings of greater than 0.5 for their accompanying sub-scales. The CR and AVE values also surpassed 0.7 and 0.5 , respectively, implying sufficient convergent validity of the second-order constructs. Destination personality was thus deemed a second-order reflective construct. In terms of discriminant validity, Table 3 reveals that the HTMT values were lower than the conservative threshold value of 0.85 (Henseler et al., 2015). Discriminant validity was therefore established.

Table 2 Measurement Model

\begin{tabular}{|c|c|c|c|c|c|}
\hline $\begin{array}{l}1^{\text {st }} \text {-order } \\
\text { construct }\end{array}$ & $\begin{array}{l}2^{\text {nd }} \text {-order } \\
\text { construct }\end{array}$ & Items & $\lambda$ & AVE & CR \\
\hline \multirow{4}{*}{ Sincerity } & & DP1 & 0.85 & \multirow{4}{*}{0.69} & \multirow{4}{*}{0.90} \\
\hline & & DP2 & 0.88 & & \\
\hline & & DP3 & 0.78 & & \\
\hline & & DP4 & 0.81 & & \\
\hline \multirow{4}{*}{ Excitement } & & DP5 & 0.76 & \multirow{4}{*}{0.57} & \multirow{4}{*}{0.84} \\
\hline & & DP6 & 0.78 & & \\
\hline & & DP7 & 0.78 & & \\
\hline & & DP8 & 0.68 & & \\
\hline \multirow{2}{*}{ Competence } & & DP9 & 0.89 & \multirow{2}{*}{0.83} & \multirow{2}{*}{0.91} \\
\hline & & DP10 & 0.93 & & \\
\hline \multirow{2}{*}{ Sophistication } & & DP12 & 0.80 & \multirow{2}{*}{0.67} & \multirow{2}{*}{0.80} \\
\hline & & DP13 & 0.83 & & \\
\hline \multirow{3}{*}{ Ruggedness } & & DP14 & 0.68 & \multirow{2}{*}{0.69} & \multirow{2}{*}{0.81} \\
\hline & & DP15 & 0.96 & & \\
\hline & & $\mathrm{ASC} 1$ & 0.91 & 0.84 & 0.94 \\
\hline
\end{tabular}




\begin{tabular}{|c|c|c|c|c|c|}
\hline \multirow{2}{*}{$\begin{array}{l}\text { Actual self- } \\
\text { congruity } \\
\text { (ASC) }\end{array}$} & & $\mathrm{ASC} 2$ & 0.93 & & \\
\hline & & ASC3 & 0.92 & & \\
\hline Ideal self- & & ISC1 & 0.89 & \multirow{3}{*}{0.81} & \multirow{3}{*}{0.93} \\
\hline \multirow[t]{8}{*}{ congruity (ISC) } & & ISC2 & 0.91 & & \\
\hline & & ISC3 & 0.90 & & \\
\hline & & Sincerity & 0.73 & \multirow{5}{*}{0.58} & \multirow{5}{*}{0.87} \\
\hline & Destination & Excitement & 0.81 & & \\
\hline & personality & Competence & 0.77 & & \\
\hline & $(D P)$ & Sophistication & 0.80 & & \\
\hline & & Ruggedness & 0.69 & & \\
\hline & & DI2 & 0.66 & \multirow{4}{*}{0.51} & \multirow{4}{*}{0.80} \\
\hline \multirow{3}{*}{$\begin{array}{l}\text { Destination } \\
\text { image (DI) }\end{array}$} & & DI3 & 0.74 & & \\
\hline & & DI4 & 0.71 & & \\
\hline & & DI5 & 0.74 & & \\
\hline \multirow{3}{*}{$\begin{array}{c}\text { Revisit } \\
\text { intention (RI) }\end{array}$} & & RI1 & 0.91 & \multirow{3}{*}{0.86} & \multirow{3}{*}{0.95} \\
\hline & & RI2 & 0.94 & & \\
\hline & & RI3 & 0.93 & & \\
\hline
\end{tabular}

$\lambda$ : loadings; AVE: average variance extracted; CR: composite reliability; DI1 was deleted (AVE $<0.5$ ); DP11 was deleted (HTMT $>0.9)$

Table 3 HTMT0.85

\begin{tabular}{lrrrrrrrrr}
\hline & ASC & COM & DI & EXC & ISC & RI & RUG & SIN & SOP \\
\hline ASC & & & & & & & & & \\
COM & 0.18 & & & & & & & & \\
DI & 0.54 & 0.42 & & & & & & & \\
EXC & 0.3 & 0.71 & 0.43 & & & & & & \\
ISC & 0.8 & 0.31 & 0.52 & 0.45 & & & & & \\
RI & 0.43 & 0.21 & 0.28 & 0.35 & 0.44 & & & & \\
RUG & 0.17 & 0.58 & 0.28 & 0.63 & 0.31 & 0.31 & & & \\
SIN & 0.24 & 0.53 & 0.25 & 0.67 & 0.35 & 0.33 & 0.76 & & \\
SOP & 0.49 & 0.85 & 0.68 & 0.81 & 0.58 & 0.4 & 0.76 & 0.6 & \\
\hline
\end{tabular}

\subsection{Structural model assessment}

Before proceeding to PLS bootstrapping, the $\mathrm{R}^{2}$ value for each exogenous variable must be checked to identify the coefficient of determination (Hair et al., 2019). All variables' $\mathrm{R}^{2}$ values were above the desired 0.1 threshold (Hair et al., 2017). For instance, destination image accounted for $15 \%$ of the variance in destination personality. Destination personality explained for $10 \%$ of the variance in actual self-congruity and $18 \%$ of the variance in ideal self-congruity. Actual self-congruity and ideal self-congruity each accounted for $18 \%$ of the variance in revisit intention. Additionally, to assess predictive power, Hair et al. (2017) and Hair et al. (2019) recommended that scholars conduct a blindfolding procedure to obtain Stone-Geisser's $\mathrm{Q}^{2}$ value and then evaluate the model's predictive relevance. All $\mathrm{Q}^{2}$ values in the current model were greater than zero $\left(\mathrm{Q}^{2}\right.$ Destination personality $=0.08, \mathrm{Q}^{2}$ Actual self-congruity $=0.08 ; \mathrm{Q}^{2}$ Ideal self-congruity $=$ $0.15 ; \mathrm{Q}^{2}$ Revisit intention $\left.=0.15\right)$, indicating an acceptable fit and satisfactory predictive relevance. 
Next, we examined our hypothesis results via a bootstrapping procedure with 5,000 subsamples; path coefficients, beta values, $t$-values, and $p$-values are listed in Table 4. Destination image exerted a positive and significant effect on destination personality $(\beta=0.39$, $t=11.28, p<0.01$ ); as such, H1 was supported. Destination personality highly positively influenced tourists' actual self-congruity and ideal self-congruity $\left(\beta_{\text {actual }}=0.31, t=7.74, p<\right.$ $\left.0.01 ; \beta_{\text {ideal }}=0.43, t=11.75, p<0.01\right)$, supporting H2 and H3. Finally, actual self-congruity $(\beta$ $=0.22, t=4.17, p<0.01)$ and ideal self-congruity $(\beta=0.24, t=4.34, p<0.01)$ were each positively and strongly related to revisit intention, lending support to H4 and H5.

Table 4 Path coefficients

\begin{tabular}{lllllll}
\hline Hypotheses & Beta Values & $\begin{array}{l}\text { Standard } \\
\text { Deviation }\end{array}$ & $\boldsymbol{t}$-value & $\boldsymbol{p}$-value & CILL & CIUL \\
\hline DI -> DP & 0.39 & 0.03 & 11.28 & $0.00^{* * *}$ & 0.33 & 0.44 \\
DP-> ASC & 0.31 & 0.04 & 7.74 & $0.00^{* * *}$ & 0.24 & 0.37 \\
DP -> ISC & 0.43 & 0.04 & 11.75 & $0.00^{* * *}$ & 0.36 & 0.48 \\
ASC -> RI & 0.22 & 0.05 & 4.17 & $0.00^{* * *}$ & 0.13 & 0.31 \\
ISC -> RI & 0.24 & 0.05 & 4.34 & $0.00^{* * *}$ & 0.14 & 0.32 \\
\hline Note: $* * * p<0.001 ; * * p<0.05 ;$ CILL: confidence interval lower limit; CIUL: confidence interval upper limit.
\end{tabular}

\subsection{Moderator analysis (MGA)}

Methodological scholars have stressed that measurement invariance must be checked prior to running MGA between two groups with SEM (Henseler et al., 2016). Whereas most approaches to evaluating measurement invariance assume common-factor models, PLS-SEM is a composite model whose latent variable scores are determined using a composite model algorithm (Henseler et al., 2016). Regarding the MICOM in MGA data, PLS-SEM is especially powerful (Henseler et al., 2016). In this study, we sought to compare a research model over two groups via a three-step approach: (1) configural invariance assessment; (2) compositional invariance assessment; (3) equal means and variances assessment (Rasoolimanesh et al., 2021). However, before performing these steps, researchers must assess their measurement model for each group (i.e., women and men in our case). Each group's factor loadings and CR and AVE values exceeded the benchmark value (see Appendix 1). Discriminant validity was also well established for each group based on HTMT values (see Appendix 2). We determined the partial measurement invariance (i.e., Steps 1 and 2) per group according to the MICOM procedure (see Table 5); doing so is critical when comparing and reporting group-specific differences in MGA (Henseler et al., 2016). The results of MICOM analysis met acceptable criteria in Step 3 (i.e., equal means and variance assessment; see Table 5). These outcomes were rare in prior 
literature. The results of Step 3 showed that measurement invariance was fully established, reflecting the suitability of our data for MGA. Guidance from Henseler et al. (2016) indicated that we could combine the three groups of data (female tourists, male tourists, and both [i.e., composite]; see Appendices 1 and 2) to verify full measurement invariance.

Upon carrying out Henseler's MGA and the permutation test (see Table 6), we found a highly significant difference for the positive effect of destination personality on ideal self-congruity. The positive association between destination personality and ideal self-congruity was stronger for female tourists compared to male tourists. H6c was thus supported. However, we observed a non-significant difference among other path coefficients and relationships for female and male tourists; as such, H6a, H6b, H6d, and H6e were not supported. Finally, the two MGA applied in this study indicated the significance/non-significance of differences between female and male tourists, enhancing the robustness of our findings. 
Table 5 Invariance Measurement Evaluation using Permutation

Compositional Invariance

Equal Mean assessment

Equal variance assessment

Measurement Partial

invariance

established

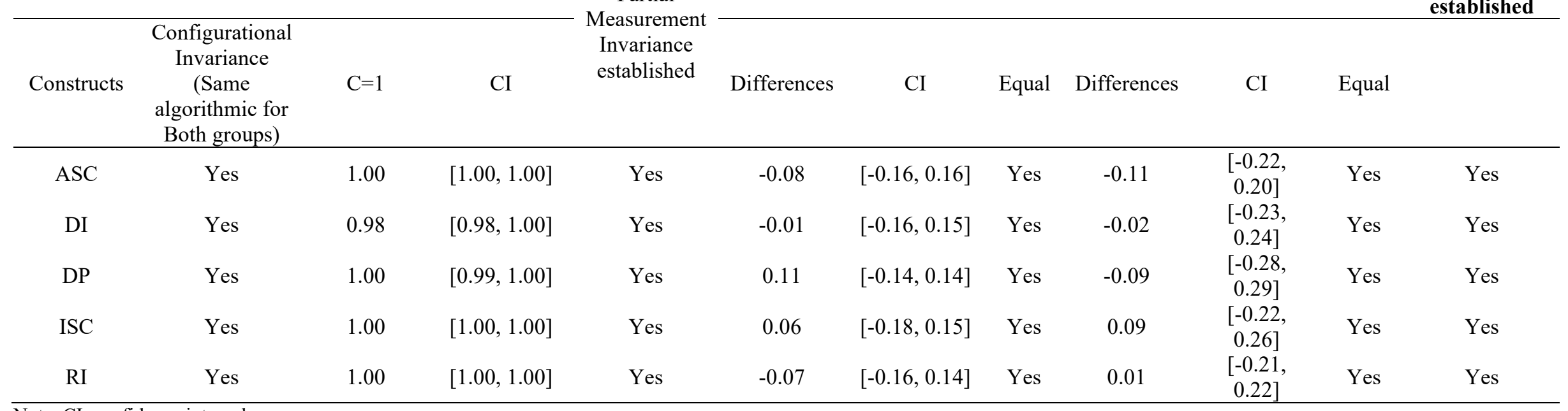

Note: CI: confidence interval.

Table 6: Results of MGA hypothesis testing

\begin{tabular}{|c|c|c|c|c|c|c|c|c|c|c|}
\hline \multirow[b]{2}{*}{ Relationships } & \multicolumn{3}{|c|}{ Path Coefficient } & \multicolumn{3}{|c|}{ Confidence Interval } & \multirow{2}{*}{$\begin{array}{c}\text { Path } \\
\text { Coefficient } \\
\text { Difference }\end{array}$} & \multicolumn{2}{|c|}{$\begin{array}{c}p \text {-value Difference (one- } \\
\text { tailed test) }\end{array}$} & \multirow[t]{2}{*}{ Supported } \\
\hline & Complete & Female & Male & Complete & Female & Male & & Permutation & $\begin{array}{l}\text { Henseler's } \\
\text { MGA }\end{array}$ & \\
\hline DI -> DP & $0.38 *$ & $0.43 *$ & $0.32 *$ & {$[0.32,0.44]$} & {$[0.35,0.49]$} & {$[0.26,0.43]$} & 0.11 & 0.12 & 0.06 & $\mathrm{No} / \mathrm{No}$ \\
\hline DP -> ASC & $0.31 *$ & $0.35^{*}$ & $0.26^{*}$ & {$[0.25,0.37]$} & {$[0.26,0.42]$} & {$[0.16,0.38]$} & 0.09 & 0.31 & 0.15 & No/No \\
\hline DP -> ISC & $0.43 *$ & $0.50 *$ & $0.28 *$ & {$[0.36,0.47]$} & {$[0.43,0.56]$} & {$[0.18,0.39]$} & 0.22 & 0.00 & 0.00 & Yes/Yes \\
\hline ASC $->$ RI & $0.22 *$ & $0.26^{*}$ & $0.23 *$ & {$[0.15,0.33]$} & {$[0.17,0.37]$} & {$[0.07,0.38]$} & 0.04 & 0.74 & 0.38 & $\mathrm{No} / \mathrm{No}$ \\
\hline ISC -> RI & $0.25^{*}$ & $0.27 *$ & $0.11^{N S}$ & {$[0.13,0.31]$} & {$[0.16,0.38]$} & {$[-0.04,0.27]$} & 0.16 & 0.14 & 0.09 & $\mathrm{No} / \mathrm{No}$ \\
\hline
\end{tabular}

not significant 


\subsection{Discussion and Conclusion}

This study involved the development of a theoretical and integrative model to inform advanced tourism marketing strategies. This study is the first of its kind to link between destination image, destination personality, self-congruity, revisit intention and gender. First, the path coefficients pointed to a direct positive and highly significant association between destination image and destination personality (H1). Scholars have also emphasized a connection between these two constructs (Chen \& Phou, 2013; Souiden et al., 2017). Therefore, if Chinese tourists hold a more positive image of New Zealand, then they are more likely to perceive its destination personality. Further, these findings support those of earlier work (Ekinci \& Hosany, 2006) revealing a cause-and-effect relationship between destination image and destination personality. In other words, Chinese tourists could have favourable impressions towards New Zealand and subsequently perceive its personality traits. The current results also partially accord with research conducted in Beijing, China with a sample of international tourists (Xie $\&$ Lee, 2013). Destination image thus appears interrelated with destination personality across distinct samples in separate destinations.

Second, as hypothesized (H2, H3, H4, H5), destination personality exerted a positive influence on self-congruity (actual and ideal), and self-congruity (i.e., actual and ideal) positively influenced revisit intention. These associations have been well documented in empirical tourism research (Usakli \& Baloglu, 2011; Kumar, 2016; Kim \& Malek, 2017; Chua et al., 2019; Liu et al., 2019; Yang et al., 2020) and conceptual tourism papers (Yang, Isa, \& Ramayah, 2020, 2021b). In terms of the impact of self-congruity on travel behaviour, a better fit between destination personality and self-congruity encourages revisit intention (Usakli \& Baloglu, 2011; Liu et al., 2019; Yang et al., 2020). Our findings further showed that selfcongruity can predict Chinese tourists' intentions to revisit New Zealand. More specifically, a closer match between New Zealand's personality and Chinese tourists' own personalities should promote their interest in returning to the country. Our results confirm the applicability of the theory of self-congruity in New Zealand.

More importantly, we found that our integrated theoretical model highlighted gender as the moderator in explaining Chinese tourists' intentions to revisit New Zealand. The PLS-MGA results indicated a highly significant difference in destination personality's impacts on ideal self-congruity across female and male Chinese tourists (H6c). Destination personality strongly affected ideal congruity among female Chinese tourists; for male Chinese tourists, the 
influence of destination personality on ideal self-congruity was slight. The theory of selfcongruity integrates one's affective and cognitive understanding of who and what they are (Malär et al., 2011). Our findings implied that female Chinese tourists did not identify New Zealand as having a favourable destination personality which reflected their true selves (actual self-congruity) but did find New Zealand's personality to enhance their self-esteem (ideal selfcongruity). This finding aligns with research attributing female heterogeneity to more complex gender-related factors such as self-concept/image (Khoo-Lattimore \& Prayag, 2016). Overall, our results suggest that more gender-oriented studies are needed which focus on Chinese women to engender a clearer understanding of these tourists' cognition and emotions.

Surprisingly, our findings did not reveal any differences between female and male Chinese tourists' destination image, destination personality, actual self-congruity, and revisit intentions (H6a, H6b, H6d, H6e). These results are consistent with prior studies in contexts such as South Korea, the UK, and Belgium (Kim et al., 2018; Moons et al, 2020; Yang et al., 2020). In sum, gender did not moderate the proposed framework in this study except for the variables of destination personality and ideal self-congruity. However, our unexpected findings also partially contrast with previous tourism research indicating that female and male tourists have different destination perceptions (Pan et al., 2021). Similarly, hospitality scholars have suggested that female guests are more inclined than men to revisit a restaurant for dining (Han \& Ryu, 2007). The studies' varied research settings or sample characteristics may have led to associated inconsistencies in results.

\subsection{Theoretical contributions}

The present study made theoretical contributions to tourism literature. First, despite previous tourism literature has explored factors affecting revisit intention through the theory of selfcongruity (Usakli \& Baloglu, 2011; Liu et al., 2012; Chua et al., 2019; Yang et al., 2020), destination image has been less incorporated into self-congruity models in tourism, especially regarding Chinese tourists' intentions to revisit New Zealand. Hence, the current study extended Usakli and Baloglu's (2011) model by confirming the correlations between destination image, destination personality, self-congruity and revisit intention.

Second, no empirical study apart from this one has investigated an integrated theoretical model encompassing destination image, destination personality, self-congruity, gender, and revisit intention. Our primary contribution involves identifying the moderating role of gender (as a 
categorical variable) in this holistic framework. Although gender has been found to moderate revisit intention in several tourism studies (Kim et al., 2018; Yang et al., 2020), prior research involved separate models. By filling this gap, our work represents the first effort to empirically examine the proposed model in the tourism literature. Interestingly, the non-significant moderating effect of gender as the categorical variable did not contribute to the proposed framework (H6a, H6b, H6d, H6e). Yet our other results revealed that gender moderated New Zealand's destination personality and tourists' ideal self-congruity (H6c). We therefore found support for the self-congruity construct when comparing female and male Chinese tourists.

Third, the current study was conducted with female and male Chinese tourists in New Zealand. This country represents an emerging study setting that has been mostly neglected, particularly in applications of Henseler's MGA and the permutation test, with the exception of a few tourism studies (Rasoolimanesh et al., 2007; Rasoolimanesh et al., 2021). Two groups of data were thus employed to cross-validate our conclusions. Through this technique, our study adds methodological value to the tourism literature.

\subsection{Practical contributions}

Besides advancing existing research by presenting an integrated model, this study provides valuable insight for tourism stakeholders such as DMOs and tourism policymakers in New Zealand. Identifying the factors that increase Chinese tourists' intentions of returning to a destination is crucial in helping DMOs and policymakers sustainably develop the Chinese tourist market and, in this case, in highlighting New Zealand as a prime travel destination.

Practically, this study's contributions will greatly affect New Zealand's economic growth and competitiveness via tourism. For instance, findings can shape key guidelines for DMOs in devising effective marketing strategies. The constructs of destination image, destination personality, and self-congruity each need to be stressed at a promotional level. Tourism marketers should capitalize on New Zealand's destination image to distinguish it from competitors. The country's beautiful scenery, natural attractions, pleasant climate, and general safety should be emphasized in marketing campaigns. Such messaging would highlight the positive image of New Zealand as a tourism destination. The slogan "land oflong white clouds" has already contributed to the nation's image. The reality program Where are We Going, Dad? has also cast New Zealand in a positive light and expanded its Chinese tourism. Therefore, 
destination marketers should leverage the country's compelling properties to promote it in China.

Our study also discovered that greater congruence between New Zealand's destination personality and Chinese tourists' personalities made these travellers more likely to return. Specific destination personality traits in New Zealand, such as sincerity, excitement, competence, sophistication, and ruggedness, appeared unique to the Chinese market (e.g., down-to-earth, charming, outdoorsy). These dimensions afforded Chinese tourists an opportunity to connect with New Zealand and feel at ease and at home, potentially persuading them to return in the future. DMOs should therefore conduct market research on Chinese tourists' personality traits before engaging in promotion. Doing so could foster a strong match between New Zealand as a potential destination and Chinese tourists. Chinese travellers may revisit New Zealand frequently because they find its destination personality similar to their own.

Moreover, the current study is the first to notify DMOs that gender differences in this model cannot be overlooked. In terms of gender, female Chinese tourists in particular appeared to perceive New Zealand's personality as reflecting how they wish to be. Given the distinctions between female and male Chinese tourists, strategic planners can tailor their marketing methods to respectively promote female and male Chinese tourists' revisit intentions. It is crucial for DMOs to highlight personality traits that match the self-concept of female Chinese tourists. The ideal self-congruity of New Zealand personality traits and target female tourists' personality traits could be enhanced through advertisements and other promotions. For instance, advertising agencies could create campaigns framing New Zealand destinations as sincere, exciting, competent, sophisticated, and rugged, as Chinese women want to possess these types of traits. New Zealand's tourism industry could then attract a sustainable number of Chinese female visitors, including repeat tourists, based on this appealing destination personality.

\subsection{Limitations and future research}

Although our work is novel, as with any study, limitations exist. First, we only examined the direct relationships among destination image, destination personality, self-congruity, and revisit intention. To advance our model, indirect effects (i.e., mediators and serial mediators) should be investigated in future research. Findings would offer a more comprehensive view of 
revisit intention. Second, we took self-congruity as the main construct to predict revisit intention by comparing female and male Chinese tourists. To promote a clearer understanding of the theory of self-congruity, we recommend that similar comparative studies be conducted in different tourism destinations. The methodological limitations of this research must be highlighted as well: SEM focused on the correlations between latent constructs in our case. Other important information, such as descriptive statistics (e.g., means and standard deviation), were not computed. Some scholars consider SEM and other estimation methods problematic because factor scores can be calculated using different approaches and may be ambiguous (Kline, 2005), requiring further explanation. Finally, subsequent studies should move beyond cross-sectional and self-report data to include interviews or triangulated observations (e.g., against self-report measures or on-site approaches) to explore tourists' revisit intentions. 


\section{References}

Aaker, J. L. (1999). The malleable self: The role of self-expression in persuasion. Journal of marketing research, 36(1), 45-57.

Abel, J. I., Buff, C. L., \& O’Neill, J. C. (2013). Actual self-concept versus ideal self-concept. Sport, Business and Management: An International Journal. 3(1), 78-96.

Assaker, G. (2014). Examining a hierarchical model of Australia's destination image. Journal of Vacation Marketing, 20(3), 195-210.

Allameh, S. M., Pool, J. K., Jaberi, A., Salehzadeh, R., \& Asadi, H. (2015). Factors influencing sport tourists' revisit intentions: The role and effect of destination image, perceived quality, perceived value and satisfaction. Asia Pacific Journal of Marketing and Logistics. 27 (2), 191-207.

Bagozzi, R. (1978). The construct validity of the affective, behavioural, and cognitive components of attitude by analysis of covariance structures. Multivariate Behavioural Research, 13, 9-31.

Baloglu, S., \& McCleary, K. W. (1999). A model of destination image formation. Annals of tourism research, 26(4), 868-897.

Beerli, A., \& Martín, J. D. (2004). Tourists' characteristics and the perceived image of tourist destinations: a quantitative analysis - a case study of Lanzarote, Spain. Tourism management, 25(5), 623-636.

Bem, S. L. (1981). Gender schema theory: A cognitive account of sex typing. Psychological review, 88(4), 354

Brislin, R. W. (1970). Back-translation for cross-cultural research. Journal of Cross-Cultural Psychology, 1(3), $185-216$.

Chaulagain, S., Wiitala, J., \& Fu, X. (2019). The impact of country image and destination image on US tourists' travel intention. Journal of Destination Marketing \& Management, 12, 1-11.

Chen, C. F., \& Phou, S. (2013). A closer look at destination: Image, personality, relationship and loyalty. Tourism management, 36, 269-278.

Chen, J. S., \& Uysal, M. (2002). Market positioning analysis: A hybrid approach. Annals of tourism research, 29(4), 987-1003.

Chen, X., \& Mak, B. (2020). Understanding Chinese girlfriend getaways: an interdependence perspective. Annals of Tourism Research, 81, 102878.

Chua, B. L., Kim, H. C., Lee, S., \& Han, H. (2019). The role of brand personality, self- congruity, and sensory experience in elucidating sky lounge users' behaviour. Journal of Travel \& Tourism Marketing, 1-14.

Dann, G. M. (1996). Tourists' images of a destination-an alternative analysis. Journal of Travel \& Tourism Marketing, 5(1-2), 41-55.

Das, G. (2015). Impacts of retail brand personality and self-congruity on store loyalty: The moderating role of gender. Journal of Retailing and Consumer Services 21 (2), 130-8. 
Das, G., \& Khatwani, G. (2018). E-tailer personality and behavioural intentions: the application of selfcongruity theory. Journal of Strategic Marketing, 26(4), 283-297.

Eagly, A., Wood, N., 1991. Explaining sex differences in social behaviour: a meta-analytic perspective. Personality and Social Psychology Bulletin, 17 (3), 306-315.

Ekinci, Y., \& Riley, M. (2003). An investigation of self-concept: actual and ideal self-congruence compared in the context of service evaluation. Journal of Retailing and Consumer Services, 10(4), 201-214.

Ekinci, Y., \& Hosany, S. (2006). Destination personality: An application of brand personality to tourism destinations. Journal of travel research, 45(2), 127-139.

Ekinci, Y., Sirakaya-Turk, E., \& Preciado, S. (2013). Symbolic consumption of tourism destination brands. Journal of Business Research, 66(6), 711-718.

Fishbein, M., \& Ajzen, I. (1977). Belief, attitude, intention, and behaviour: An introduction to theory and research. Reading, MA USA: Addison e Wesley.

Fisher, E., \& Arnold, S. J. (1994). Sex, gender identity, gender role attitudes, and consumer behaviour. Psychology \& Marketing,11(2),163-182.

Fu, H., Ye, B. H., \& Xiang, J. (2016). Reality TV, audience travel intentions, and destination image. Tourism Management, 55, 37-48.

Gallarza, M. G., Saura, I. G., \& García, H. C. (2002). Destination image: Towards a conceptual framework. Annals of tourism research, 29(1), 56-78.

Gyulavári, T., \& Malota, E. (2019). The role of culture personality and self-congruity in the evaluation of cultures as destinations. Tourism Review. 74 (3), 632-645.

Hair, J. F., Risher, J. J., Sarstedt, M., \& Ringle, C. M. (2019). When to use and how to report the results of PLSSEM. European Business Review, 31 (1), 2-24.

Hair, J.F., Black, W.C., Babin, B. J., \& Anderson, R.E. (2009). Multivariate data analysis (7th ed.). NJ: Pearson prentice hall.

Hair, J. F., Hult, G. T. M., Ringle, C. M., \& Sarstedt, M. (2014). A primer on partial least squares structural equation modelling (PLSSEM). Thousand Oaks: Sage.

Hair, J.F., Hult, G.T.M., Ringle, C. and Sarstedt, M. (2017), A Primer on Partial Least Squares Structural Equation Modeling (PLS-SEM), Sage Publications, Thousand Oaks, CA.

Hallmann, K., Zehrer, A., \& Müller, S. (2015). Perceived destination image: An image model for a winter sports destination and its effect on intention to revisit. Journal of Travel Research, 54(1), 94-106.

Han, H., \& Ryu, K. (2007). Moderating role of personal characteristics in forming restaurant customers' behavioural intentions: An upscale restaurant setting. Journal of Hospitality \& Leisure Marketing, $15(4), 25-54$.

Han, H., Meng, B., \& Kim, W. (2017). Bike-traveling as a growing phenomenon: Role of attributes, value, satisfaction, desire, and gender in developing loyalty. Tourism Management, 59, 91-103. 
Henseler, J., C. Ringle., \& M. Sarstedt. (2016). Testing Measurement Invariance of Composites Using Partial Least Squares. International Marketing Review 33 (3), 405-31.

Henseler, J., Ringle, C., \& d Sarstedt, M. (2015). A new criterion for assessing discriminant validity in variancebased structural equation modelling. Journal of the Academy of Marketing Science, 43 (1)115-135.

Henseler, J., Ringle, C. M., \& Sinkovics, R. R. (2009). The use of partial least squares path modelling in international marketing. In New challenges to international marketing. Emerald Group Publishing Limited.

Hosany, S., \& Martin, D. (2012). Self-image congruence in consumer behaviour. Journal of Business Research, 65(5), 685-691.

Hosany, S., Ekinci, Y., \& Uysal, M. (2006). Destination image and destination personality: An application of branding theories to tourism places. Journal of Business Research, 59(5), 638-642.

Huaman-Ramirez, R., Merunka, D., \& Maaninou, N. (2021). Destination personality effects on tourists' attitude: the role of self-congruity and ambiguity tolerance. Journal of Strategic Marketing, 1-25.

Huang, S., \& van der Veen, R. (2019). The moderation of gender and generation in the effects of perceived destination image on tourist attitude and visit intention: A study of potential Chinese visitors to Australia. Journal of vacation marketing, 25(3), 375-389.

Isa, S. M., \& Ramli, L. (2014). Factors influencing tourist visitation in marine tourism: lessons learned from FRI Aquarium Penang, Malaysia. International journal of culture, tourism and hospitality research. 8 (1), 103-117

Jalilvand, M. R., Samiei, N., Dini, B., \& Manzari, P. Y. (2012). Examining the structural relationships of electronic word of mouth, destination image, tourist attitude toward destination and travel intention: An integrated approach. Journal of Destination Marketing \& Management, 1(1-2), 134-143.

Jiang, Y., \& Chen, N. C. (2019). Event attendance motives, host city evaluation, and behavioural intentions. International Journal of Contemporary Hospitality Management, 31(8), 3270-3286.

Jones, A. H. (2011). Visual and Verbal Gender Cues in the Televised Coverage of the 2010 Winter Olympics. International Journal of Interdisciplinary Social Sciences, 6(2). 199-216.

Jeong, Y., \& Kim, S. (2019). A study of event quality, destination image, perceived value, tourist satisfaction, and destination loyalty among sport tourists. Asia Pacific Journal of Marketing and Logistics. 32 (4), 940-960.

Kani, Y., Aziz, Y. A., Sambasivan, M., \& Bojei, J. (2017). Antecedents and outcomes of destination image of Malaysia. Journal of Hospitality and Tourism Management, 32, 89-98

Karagöz, D., Işık, C., Dogru, T., \& Zhang, L. (2020). Solo female travel risks, anxiety and travel intentions: Examining the moderating role of online psychological-social support. Current Issues in Tourism, 118.

Khazaei Pool, J., Khodadadi, M., \& Asadi, A. (2018). The impact of congruence between self-concept and destination personality on behavioural intentions for visiting an Islamic-historical destination. Tourism and Hospitality Research, 18(3), 378-387. 
Kaur, A., Chauhan, A., \& Medury, Y. (2016). Destination image of Indian tourism destinations: An evaluation using correspondence analysis. Asia Pacific Journal of Marketing and Logistics. 28 (3), 499-524.

Khoo-Lattimore, C., \& Prayag, G. (2016). Accommodation preferences of the girlfriend getaway market in Malaysia. International Journal of Contemporary Hospitality Management, 28 (12), 2748-2770.

Kim, H., \& Richardson, S. L. (2003). Motion picture impacts on destination images. Annals of Tourism Research, 30(1), 216-237.

Kim, W., \& Malek, K. (2017). Effects of self-congruity and destination image on destination loyalty: The role of cultural differences. Anatolia, 28(1), 1-13.

Kim, W., Malek, K., Kim, N., \& Kim, S. (2018). Destination personality, destination image, and intent to recommend: The role of gender, age, cultural background, and prior experiences. Sustainability, 10(1), 87

Kline, R. B. (2005). Principles and practice of structural equation modelling. New York, NY: Guilford Press.

Kumar, V. (2016). Examining the role of destination personality and self-congruity in predicting tourist behaviour. Tourism Management Perspectives, 20, 217-227.

Kumar, V., \& Nayak, J.K. (2018). Destination personality: scale development and validation. Journal of Hospitality \& Tourism Research, 42 (1), 3-25.

Li, M., Cai, L. A., Lehto, X. Y., \& Huang, J. (2010). A missing link in understanding revisit intention-The role of motivation and image. Journal of Travel \& Tourism Marketing, 27(4), 335-348.

Liu, C. R., Lin, W. R., \& Wang, Y. C. (2012). Relationship between self-congruity and destination loyalty: Differences between first-time and repeat visitors. Journal of Destination Marketing \& Management, $1(1-2), 118-123$.

Liu, Z., Huang, S., \& Liang, S. (2019). Does Brand personification matter in consuming tourism real estate products? A perspective on brand personality, self-congruity and brand loyalty. Journal of China Tourism Research, 15(4), 435-454.

Luna-Cortés, G., López-Bonilla, J. M., \& López-Bonilla, L. M. (2019). Self-congruity, social value, and the use of virtual social networks by generation y travellers. Journal of Travel Research, 58(3), 398-410.

Malär, L., Krohmer, H., Hoyer, W. D., \& Nyffenegger, B. (2011). Emotional brand attachment and brand personality: The relative importance of the actual and the ideal self. Journal of marketing, 75(4), 3552.

Matzler, K., Strobl, A., Stokburger-Sauer, N., Bobovnicky, A., \& Bauer, F. (2016). Brand personality and culture: The role of cultural differences on the impact of brand personality perceptions on tourists' visit intentions. Tourism Management, 52, 507-520.

Moons, I., De Pelsmacker, P., \& Barbarossa, C. (2020). Do personality-and self-congruity matter for the willingness to pay more for ecotourism? An empirical study in Flanders, Belgium. Journal of Cleaner Production, 272, 122866.

Pan, L., Lu, L., \& Gursoy, D. (2020). Traveling to a Gendered Destination: A Goal-Framed Advertising Perspective. Journal of Hospitality \& Tourism Research, 44(3), 499-522. 
Pan, L., Lu, L., \& Zhang, T. (2021). Destination gender: Scale development and cross-cultural validation. Tourism Management, 83, 104225.

Pan, L., Zhang,M., Gursoy, D., \& Lu, L. (2017). Development and validation of a destination personality scale for mainland Chinese travellers, Tourism Management, 59, 338-348.

Pung, J. M., Yung, R., Khoo-Lattimore, C., \& Del Chiappa, G. (2019). Transformative travel experiences and gender: A double duoethnography approach. Current Issues in Tourism, 1-21. https://doi.org/10.1080/13683500.2019.1690434

Rasoolimanesh, S. M., Khoo-Lattimore, C., Md Noor, S., Jaafar, M., \& Konar, R. (2021). Tourist engagement and loyalty: gender matters?. Current Issues in Tourism, 24(6), 871-885.

Rasoolimanesh, S. M., Roldán, J. L., Jaafar, M., \& Ramayah, T. (2017). Factors influencing residents' perceptions toward tourism development: Differences across rural and urban world heritage sites. Journal of Travel Research, 56(6), 760-775.

Riquelme, H.E., \& Rios, R.E. (2010). The moderating effect of gender in the adoption of mobile banking. International Journal of Bank Marketing, 28 (5) 328341. https://doi.org/10.1108/02652321011064872

Ringle, C. M., Wende, S., \& Becker, J. M. (2015). SmartPLS 3. SmartPLS GmbH, Boenningstedt. Journal of Service Science and Management, 10(3).

Ringle, C. M., Sarstedt, M., \& Straub, D. W. (2012). Editor's comments: A critical look at the use of PLS-SEM in MIS quarterly. MIS Quarterly, 36(1), 3-14.

Ryan, C., \& Mo, X. (2002). Chinese visitors to New Zealand-demographics and perceptions. Journal of Vacation Marketing, 8(1), 13-27.

Ross, I. (1971). Self-concept and brand preference. The Journal of Business, 44(1), 38-50.

Šagovnović, I., \& Kovačić, S. (2020). Influence of tourists' sociodemographic characteristics on their perception of destination personality and emotional experience of a city break destination. International Journal of Tourism Cities. 7 (1), 200-223.

Sarstedt, M., Hair Jr, J. F., Cheah, J. H., Becker, J. M., \& Ringle, C. M. (2019). How to specify, estimate, and validate higher-order constructs in PLS-SEM. Australasian Marketing Journal (AMJ), 27(3), 197-211.

Shamah, R. A., Mason, M. C., Moretti, A., \& Raggiotto, F. (2018). Investigating the antecedents of African fast food customers' loyalty: A self-congruity perspective. Journal of Business Research, 86, 446-456.

Sirgy, M. J. (1982). Self-concept in consumer behaviour: A critical review. Journal of consumer research, 9(3), 287-300.

Sirgy, M. J., \& Su, C. (2000). Destination image, self-congruity, and travel behaviour: Toward an integrative model. Journal of Travel Research, 38, 340-352.

Sirgy, M. J., Grewal, D., \& Mangleburg, T. (2000). Retail environment, self-congruity, and retail patronage: An integrative model and a research agenda. Journal of Business research, 49(2), 127-138.

Sirgy, M. J., Grewal, D., Mangleburg, T. F., Park, J. O., Chon, K. S., Claiborne, C. B., ... \& Berkman, H. (1997). Assessing the predictive validity of two methods of measuring self-image congruence. Journal of the academy of marketing science, 25(3), 229-241. 
Souiden, N., Ladhari, R., \& Chiadmi, N. E. (2017). Destination personality and destination image. Journal of Hospitality and Tourism Management, 32, 54-70.

Statistics New Zealand. (2019). Visitor numbers from China fall short of last year's record. Retrieved from https://www.stats.govt.nz/news/visitor-numbers-from-china-fall-short-of-last-years-record.

Stylos, N., Vassiliadis, C. A., Bellou, V., \& Andronikidis, A. (2016). Destination images, holistic images and personal normative beliefs: Predictors of intention to revisit a destination. Tourism Management, 53, $40-60$.

Tran, P. K. T., Nguyen, P. D., Le, A. H. N., \& Tran, V. T. (2021). Linking self-congruity, perceived quality and satisfaction to brand loyalty in a tourism destination: the moderating role of visit frequency. Tourism Review. Vol. ahead-of-print No. ahead-of-print.

Tourism New Zealand (2017). Heart of the Long white cloud campaign launches in China Retrieved from https://www.tourismnewzealand.com/news/heart-of-the-long-white-cloud-campaign-launches-inchina/

Tourism New Zealand. (2019). About the industry. Retrieved from https://www.tourismnewzealand.com/about/about-the-industry

Um, S., \& Crompton, J. L. (1990). Attitude determinants in tourism destination choice. Annals of tourism research, 17(3), 432-448.

Usakli, A., \& Baloglu, S. (2011). Brand personality of tourist destinations: An application of self-congruity theory. Tourism Management, 32(1), 114-127.

Wang, C., Qu, H., \& Hsu, M. K. (2016). Toward an integrated model of tourist expectation formation and gender difference. Tourism Management, 54, 58-71.

Wen, J., Klarin, A., Goh, E., \& Aston, J. (2020). A systematic review of the sex trafficking-related literature: Lessons for tourism and hospitality research. Journal of Hospitality and Tourism Management, 45, 370376

World journey (2021). sun, sand and wildlife. Retrieved from https://worldjourneys.co.nz/sun-sand-wildlife/ world.

Xie, K. L., \& Lee, J. S. (2013). Toward the perspective of cognitive destination image and destination personality: the case of Beijing. Journal of Travel and Tourism Marketing, 30(6), 538-556.

Yang, E. C. L., Khoo-Lattimore, C., \& Arcodia, C. (2018). Power and empowerment: How Asian solo female travellers perceive and negotiate risks. Tourism Management, 68, 32-45.

Yang, S., Isa, S.M., Ramayah, T., Blanes, R., \& Kiumarsi, S. (2020). The Effects of Destination Brand Personality on Chinese tourists' Revisit Intention to Glasgow: An Examination across Gender. Journal of International Consumer Marketing, 32(5), 435-452.

Yang, S., Isa, S. M., \& Ramayah, T. (2020). A Theoretical Framework to Explain the Impact of Destination Personality, Self-Congruity, and Tourists' Emotional Experience on Behavioural Intention. Sage Open, 10(4), 2158244020983313.

Yang, S., Isa, S. M., \& Ramayah, T. (2021a). How are destination image and travel intention influenced by misleading media coverage? Consequences of COVID-19 outbreak in China. Vision, 0972262921993245. 
Yang, S., Isa, S. M., \& Ramayah, T. (2021b). Uncertainty avoidance as a moderating factor to the self-congruity concept: the development of a conceptual framework, Sage Open, 11(1), doi.org/10.1177/21582440211001860

Ye, S., Wei, W., Wen, J., Ying, T., \& Tan, X. (2020). Creating memorable experience in rural tourism: A comparison between domestic and outbound tourists. Journal of Travel Research, 0047287520951641.

Zhang, H., Wu, Y., \& Buhalis, D. (2018). A model of perceived image, memorable tourism experiences and revisit intention. Journal of destination marketing \& management, 8, 326-336.

Zhang, Y. G., Dang, Y. M., Brown, S. A., \& Chen, H. (2017). Investigating the impacts of avatar gender, avatar age, and region theme on avatar physical activity in the virtual world. Computers in Human Behaviour, $68,378-387$. 


\section{Author Biographies}

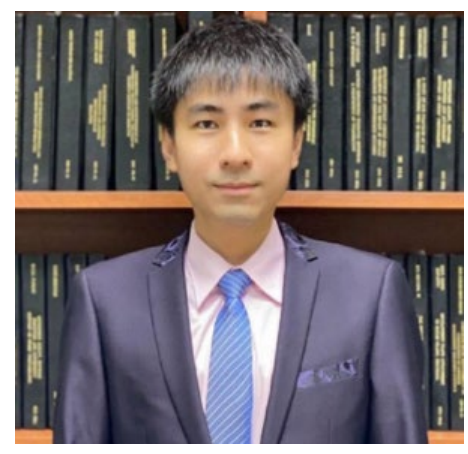

Dr. Shaohua Yang is currently a Post-Doctoral Fellow from Graduate School of Business, Universiti Sains Malaysia. He holds Ph.D. in Tourism Marketing at Graduate School of Business, Universiti Sains Malaysia. He was also a $\mathrm{PhD}$ exchange student (Erasmus funding) in Adam Smith Business School at University of Glasgow, United Kingdom. His research interest lies in destination marketing, cross-cultural tourism, tourist behaviour and special interest tourism. He has published many articles in a variety of SSCI/Scopus journals. Currently, Shaohua Yang serves as an Editor in Sage Open (SSCI Journal) and Journal of Tourism Management Research.

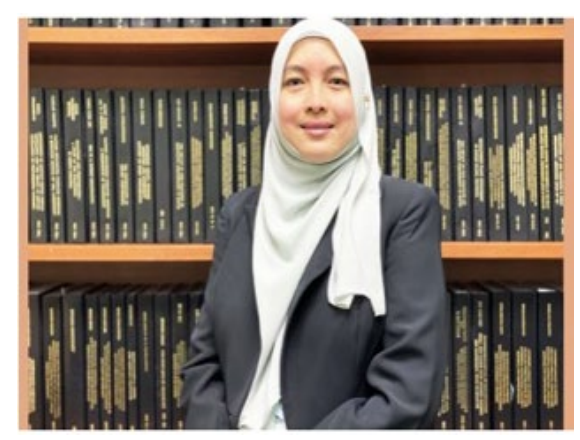

Dr. Salmi Mohd Isa is an Associate Professor and Deputy Dean of Academic, Career and International at Graduate School of Business, Universiti Sains Malaysia. Her research area focus on corporate social responsibility (CSR), tourism marketing, neuromarketing, marketing innovation and branding. She has successfully supervised five Doctor of Philosophy $(\mathrm{PhD})$ and Doctor of Administration (DBA), two post-doctoral students, and more than 30 master students. Currently, eleven Doctor of Philosophy (PhD) students are under her supervision. She also co-supervising master students from University of Glasgow, United Kingdom and FH JOANNEUM, Austria. 


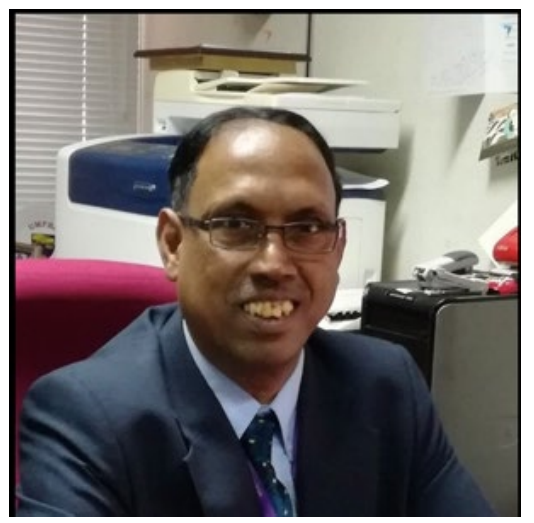

T. Ramayah, is currently a Professor of Technology Management, School of Management, Universiti Sains Malaysia, Visiting Professor Minjiang University (China), and Adjunct Professor at Sunway University and Universiti Tenaga Nasional (UNITEN), Malaysia. He is also an International Collaborative Partner (ICP) at Universiti Tunku Abdul Rahman (UTAR) Malaysia. He was also a Visiting Professor King Saud University (Kingdom of Saudi Arabia), Universiti Malaysia Sarawak (UNIMAS) and Adjunct Professor at Multimedia University previously. He has an h-index of 67 and citation of 19,113 in Google Scholar and i-10 index of 323, his h-index in SCOPUS is 34, with 5072 citations while his h-index in ISI/Clarivate is 26 with 3061 citations. His research field is about technology management, operation management and structural equation model.

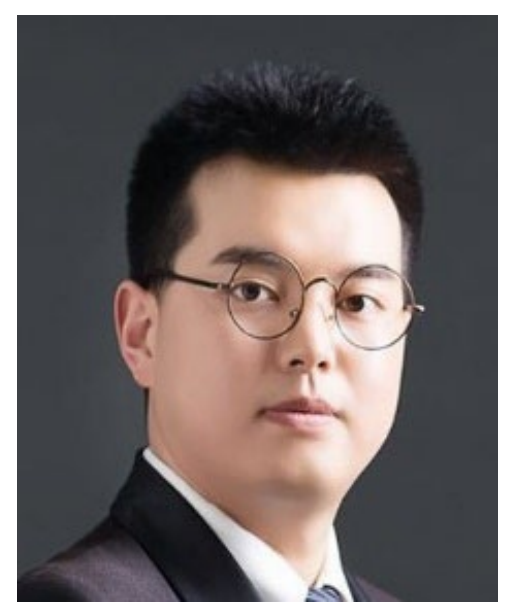

Dr. Jun Wen, PhD is currently a lecturer in tourism and services marketing in the School of Business and Law at Edith Cowan University, Australia. His current research interests lie in Chinese outbound tourism marketing, and tourist behaviours.

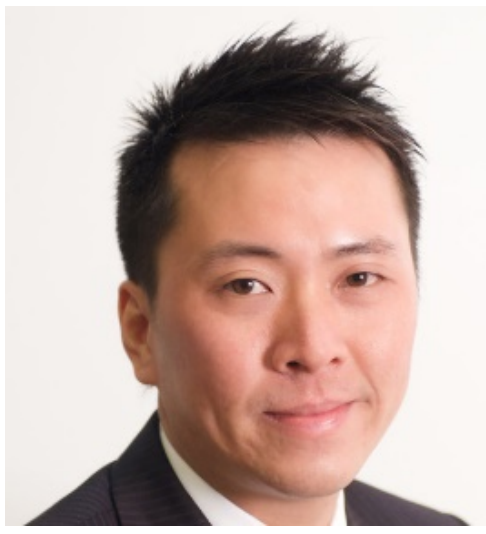

Dr. Edmund Goh, $\mathrm{PhD}$, is a Senior Lecturer, School of Business and Law, Edith Cowan University, Western Australia. He has published in leading journals such as Tourism Management, International Journal of Hospitality Management, Journal of Sustainable Tourism, International Journal of Contemporary Hospitality Management, Journal of Vacation Marketing, Journal of Tourism and Travel Marketing, Tourism Recreation Research, Tourism Management Perspectives, and Journal of Hospitality and Tourism Management. Edmund sees his research as the nexus to address education and industry gaps. 